\title{
Integrated Effect of Deficit Irrigation and Sowing Methods on Weed Dynamics and System Productivity of Maize-Cowpea Sequence on Vertisols
}

\author{
Hanamant M. Halli 1,*D, Sanganabasappa Angadi ${ }^{2}$, Prabhu Govindasamy ${ }^{1}$, $\operatorname{Raghavendra~Madar~}^{3}(\mathbb{D}$, \\ Manjanagouda S. Sannagoudar ${ }^{1}$ (D), Ahmed M. El-Sabrout ${ }^{4}$, Abed Alataway ${ }^{5}$, Ahmed Z. Dewidar ${ }^{5,6}$ \\ and Hosam O. Elansary $7,8,9, * \mathbb{D}$
}

Citation: Halli, H.M.; Angadi, S.; Govindasamy, P.; Madar, R.; Sannagoudar, M.S.; El-Sabrout, A.M.; Alataway, A.; Dewidar, A.Z.; O. Elansary, H. Integrated Effect of Deficit Irrigation and Sowing Methods on Weed Dynamics and System Productivity of Maize-Cowpea Sequence on Vertisols. Agronomy 2021, 11, 808. https:// doi.org/10.3390/agronomy11040808

Academic Editor: David Clements

Received: 2 March 2021

Accepted: 15 April 2021

Published: 20 April 2021

Publisher's Note: MDPI stays neutral with regard to jurisdictional claims in published maps and institutional affiliations.

Copyright: (c) 2021 by the authors. Licensee MDPI, Basel, Switzerland. This article is an open access article distributed under the terms and conditions of the Creative Commons Attribution (CC BY) license (https:// creativecommons.org/licenses/by/ $4.0 /)$
1 Division of Seed Technology \& Division of Crop Production, ICAR-Indian Grassland and Fodder Research Institute, Jhansi 284 003, India; prabmanikandan@gmail.com (P.G.); mssagron@gmail.com (M.S.S.)

2 Department of Agronomy, University of Agricultural Sciences, Dharwad 580 005, India; angadiss@uasd.in

3 Division of Crop Production, ICAR-Indian Institute of Soybean Research, Indore 452 001, India; raghavendra4449@gmail.com

4 Department of Applied Entomology and Zoology, Faculty of Agriculture (EL-Shatby), Alexandria University, Alexandria 21545, Egypt; elsabroutahmed@alexu.edu.eg

5 Prince Sultan Bin Abdulaziz International Prize for Water Chair, Prince Sultan Institute for Environmental, Water and Desert Research, King Saud University, Riyadh 11451, Saudi Arabia; aalataway@ksu.edu.sa (A.A.); adewidar@ksu.edu.sa (A.Z.D.)

6 Department of Agricultural Engineering, King Saud University, Riyadh 11451, Saudi Arabia

7 Plant Production Department, College of Food and Agriculture Sciences, King Saud University, Riyadh 11451, Saudi Arabia

8 Floriculture, Ornamental Horticulture, and Garden Design Department, Faculty of Agriculture (El-Shatby), Alexandria University, Alexandria 21545, Egypt

9 Department of Geography, Environmental Management, and Energy Studies, University of Johannesburg, APK Campus, Johannesburg 2006, South Africa

* Correspondence: hmhalli4700@gmail.com (H.M.H.); helansary@ksu.edu.sa (H.O.E.)

Abstract: The aim of this study was to explore the effect of sowing methods and deficit irrigation on weed dynamics, yield and water-use efficiency (WUE) of the maize-cowpea system during the summer and monsoon seasons, respectively. The field experiment was carried out for two years (2015 and 2016) using a split design with three replicates under irrigated (maize) and rainfed (cowpea) conditions on vertisols of a semi-arid region. Treatments included three sowing methods [i.e., broad bed and furrow (BBF), corrugated furrow (CF) and ridges and furrow (RF)] and four irrigation levels [i.e., irrigation once in 10 days $\left(\mathrm{I}_{10 \mathrm{D}}\right)$, irrigation at $40 \%\left(\mathrm{I}_{40}\right)$, at $50 \%\left(\mathrm{I}_{50}\right)$ and at $60 \%\left(\mathrm{I}_{60}\right)$ depletion]. The results indicated that, regardless of weed flora (monocots, dicots and sedges), the RF method produced higher weed density (2.09-2.98 No. $\mathrm{m}^{-2}$ ) compared to CF (2.00-2.80 No. $\mathrm{m}^{-2}$ ) and BBF (1.85-2.64 No. $\mathrm{m}^{-2}$ ) in maize at 30 and 60 days after sowing (DAS). The RF method with irrigation at $\mathrm{I}_{40}$ and $\mathrm{I}_{50}$ recorded significantly higher weed density, followed by the $\mathrm{CF}$ and BBF method. A similar trend was also observed with dry weight of weeds (monocot; $24.19 \%$, dicot; $25.52 \%$, and sedges; $29.80 \%$ ) in maize at 30 and 60 DAS. Higher weed density and dry weight of weeds in the RF method with $\mathrm{I}_{40}$ was due to higher soil moisture availability and higher nutrient uptake due to larger lateral wetting of the soil and greater water use (29.27\%). However, the BBF method favoured the growth of weeds (9.33-16.60\%) in cowpea at 55 DAS and coped under rain-fed situation over CF and $\mathrm{RF}$. The CF with moderate depletion $\left(\mathrm{I}_{50}\right)$ method produced significantly higher maize equivalent yield (MEY) of cowpea $\left(10,000 \mathrm{~kg} \mathrm{ha}^{-1}\right)$ with considerable reduction in the total water usage $(19.33 \%)$. Therefore, under a water scarcity situation, growers can practice $\mathrm{CF}$ and $\mathrm{I}_{50}$ for higher yield and WUE of maize-cowpea sequence cropping.

Keywords: irrigation scheduling; summer maize; system yield; weed dry weight; water use efficiency 


\section{Introduction}

The Indian population has grown by more than $235 \%$ over the past six decades, coinciding with a significant increase in food production [1]. Consequently, the country has achieved self-sufficiency in food production, particularly cereals, by influencing the local environment through increased land, water and nutrient use [2]. At the global level, India is the largest consumer of fresh water and $91 \%$ of it are mainly consumed in food grain production [3]. At the same time, the depletion of groundwater has increased by $23 \%$ from 2000 to 2010 and is a major concern for future cereal production and selfsufficiency [4]. Cereals consume about $50 \%$ of the total water used in food production due to their significant share in Indian diets [5]. Among cereals, maize (Zea mays L.) is the third most important crop grown throughout a wide range of climates and contributing by $36 \%$ to global food grain production next to rice and wheat [6]. It is intended for multiple purposes such as food $(23 \%)$, feed (12-15\%), and other purposes. Similarly, cowpea (Vigna ungiculata L.) is one of the important legume crops grown for multiple purposes such as, green pods, dry seeds, fodder and as a green manure crop [7]. Moreover, pulses play an important role in the Indian diet, therefore nutritionists consider supplementation of pulses with cereal-based diets are one of the best possible options to mitigate the problems associated with protein malnutrition. Therefore, cowpea is mainly grown as intercrop or in sequence to improve the resource use efficiency and system productivity of maize due to shorter in duration, less competitive and symbiotic nitrogen fixer. However, in recent times, the spatial and temporal variability of rainfall and the shortage of irrigation water have been a challenge to the sustainability of maize-based cropping systems [8]. Despite water scarcity, globally there is a wider variation in terms of measured average water productivity of maize due to water losses through evaporation, runoff, leaching, percolation means and uptake by weeds [9]. Among the many causes, the loss of water caused by weeds is one of the least concentrated aspects of irrigated farming.

Weeds are a major biotic constraint responsible for reducing crop yields. It has been estimated that the actual total economic loss due to weeds in India is approximately 11 billion dollars in 10 field crops and the loss is in the range of 13.8-35.8\% [10]. Similarly, weed infestation is the major limitation of the maize crop due to its wider spacing and results in an economic loss of approximately $25.3-31 \%$, and in cowpea it is about $25 \%$ to $76 \%$ [10-12]. In addition to yield loss, the indirect effect of weeds is significant in terms of competition for growth resources, harbouring other crop pests, interfering with water management and diminishing crop quality [13]. Weeds also cause significant water loss through higher transpiration and accumulation of biomass, henceforth contributing to the agricultural cost [14]. For example, the water loss due to weeds in sugarbeet and tomato under high weed competition was estimated at about $60 \mathrm{~mm} \mathrm{ha}^{-1}$ and it would increase the production costs by $\$ 22 \mathrm{ha}^{-1}$ [14].

Several previous studies have indicated that increasing in crop competitiveness is one of the goals of sustainable weed management. This can be achieved by narrowing crop space, increasing seed rate, changing sowing methods, using a weed suppressive crop/cultivar, and precious application of water and nutrients $[15,16]$. In this context, a deficit irrigation strategy, intercropping and altered sowing methods have captured the attention of researchers and planners and has been widely accepted as an important strategy for water scare areas in recent times [17]. The objective of deficit irrigation is to stabilize crop yields by enhancing water productivity $[18,19]$. Therefore, irrigating the crop root zone with appropriate moisture deficit under suitable sowing methods is of viable option to reduce the water usage, to monitor the weeds, crop yield by reducing the soil wetting zone. The reduction in yield due to deficit irrigation is insignificant in comparison to the benefits obtained by diverting the water saved to irrigate subsequent crops [20]. In the US, it was reported that the reduction in wheat grain yield was only $13 \%$ with the imposition of $60 \%$ deficit irrigation [21]. Similarly, sowing methods have a direct effect on crop yield, solar energy capture and evaporation, and thus an indirect effect on water-use efficiency (WUE). Sowing methods affect crop yield by influencing seedling establishment, 
rooting, the moisture extraction pattern, and smothering weeds [22]. Previously, authors have reported the importance of sowing methods such as broad bed and furrow, shallow furrow, and wider ridges and furrow on the growth, nutrient uptake and yield of maize and cowpea $[7,20]$ under irrigated as well as rainfed conditions. It was found that altered land configuration has influenced the weed composition, crop growth and productivity of maize-French bean-toria cropping system [23,24]. Likewise, in peanut [25] found that overall dry weight of weeds decreased by $25.66-25.71 \%$ due to reduced irrigation by $60 \%$. Uncontrolled irrigation not only depletes ground water reserves, but may leach nutrients and other chemicals from agricultural lands and this can also allow weeds to grow in irrigated agriculture [26]. Thus, there is a tremendous scope to maintain the productivity with $20-40 \%$ less water by eliminating the water loss or weed competition through better crop cultivation. Weeds are very dynamic in nature and vary due to differences in soil moisture under different sowing methods. The optimal soil moisture and space may allow weeds to flourish and compete with resources, hence the impact of irrigation on weed growth is a pivotal component of any modern crop production system [26]. It was found that ridges and furrows are the most common method of irrigation worldwide which wets the entire fields and allows water to seep and increase the weed pressure in the irrigated furrows [27]. However, in reality other crop management practices such as sowing methods, plant populations, crop nutrition and irrigation practices also determine the efficacy of weed management practices.

The study of how other crop management practices affect the presence and distribution of weeds has been comparatively less reported. Given the changing scenario and resource exhaustion in modern agriculture, it is necessary to explore crop management practices from different perspectives. Thus, we hypothesized that different sowing methods and deficit irrigation will influence water usage, nutrient uptake and weeds growth without affecting the crop yield. In this context, a study was planned with an objective, to evaluate the effect of deficit irrigation and sowing methods on weed density and biomass, water usage, nutrient uptake and yield in maize-cowpea sequence cropping system under semiarid conditions.

\section{Materials and Methods}

\subsection{Experimental Location and Weather}

The experiment was conducted at the University of Agricultural Sciences, Main Agricultural Research Station, Dharwad, Karnataka, during the summer and rainy season of 2015 and 2016. The research station lies between the western hilly zone (zone 9) and the northern dry zone (zone 3 ) and is largely part of the northern transition zone (zone 8) of Karnataka. Further details of the experimental location and mean weather during maize-cowpea growth period have been already reported $[7,19]$. The site soil type was clay (vertisols) with a bulk density of $1.24 \mathrm{~g} \mathrm{~cm}^{-3}$, a field capacity of $32.4 \%$, and a permanent wilting point of $18 \%$. The physical and chemical properties of the soil are explained in detail in Table 1.

\subsection{Sowing Methods and Crop Agronomy}

Different sowing methods like Broad Bed and Furrows (BBF), Corrugated Furrows $(\mathrm{CF})$, and Ridges and Furrows (RF) have been prepared with defined specifications. The furrow depth for BBF ( $12.5 \mathrm{~cm}$ height with $90 \mathrm{~cm}$ wide beds), $\mathrm{CF}$ (shallow depth; $10 \mathrm{~cm}$ ) and RF (deeper depth; $25 \mathrm{~cm}$ ) has been maintained. The experiment was designed with a split plot design and all experimental units were replicated three times. Three sowing methods (i.e., $\mathrm{BBF}, \mathrm{CF}$, and $\mathrm{RF}$ ) were randomly assigned to main plots and four irrigation levels (i.e., $\mathrm{I}_{10 \mathrm{D}}$; irrigation once in 10 days, $\mathrm{I}_{40}$; irrigation at $40 \%$, $\mathrm{I}_{50}$; irrigation at $50 \%$, and $\mathrm{I}_{60}$; irrigation at $60 \%$ depletion) into sub plots. The detailed arrangement of the experimental units was previously presented by [19]. It was ensured that the same number of plants $\left(32 \mathrm{~m}^{2}\right)$ was present in each sowing configuration. Separate irrigation channels were prepared for each plot to maintain the treatment effect and prevent the inflow of 
rain or excess irrigation water into the maize field. Similarly, cowpea (var. DC-15, UAS Dharwad-580005, Karnataka) was sown on the undisturbed existing maize plots (i.e., BBF, $\mathrm{CF}$, and RF) by manual dibbling at a spacing of $60 \times 10 \mathrm{~cm}$ immediately after the harvest of maize (July). Later, thinning was done in order to avoid competition. Cowpea was cultivated in residual soil moisture and fertility without irrigation or fertilizer application. The initial flush of weeds during the crop establishment stage of maize and cowpea was manually removed and, subsequently, there was no weeding required. The preventive measures were taken against early instar stem borer (Chilo partellus, Swinhoe) by spraying Imamectin benzoate at $0.25 \mathrm{~mL} \mathrm{~L}^{-1}$ and cypermetrin at $0.5 \mathrm{~mL} \mathrm{~L}^{-1}$ at later stages [ 50 days after sowing (DAS)] in maize. Likewise, in cowpea care was taken against defoliators (Epilachna varivestis) by spraying profenophos at $2 \mathrm{~mL} \mathrm{~L}^{-1}$ and flubendamide at $0.3 \mathrm{~mL} \mathrm{~L}^{-1}$ against pod borer (Maruca vitrata Fab. Syn. Maruca testulalis Geyer).

Table 1. Soil physical and chemical properties for the experimental site.

\begin{tabular}{|c|c|c|c|c|}
\hline Sl. No. & Particulars & Value & Method Employed & Reference \\
\hline \multirow[t]{9}{*}{ I. } & Physical properties & & & \\
\hline & - $\quad$ Coarse sand $(\%)$ & 6.8 & & \\
\hline & - $\quad$ Fine sand $(\%)$ & 12.0 & & \\
\hline & - $\quad$ Silt (\%) & 33.9 & International pipette method & [28] \\
\hline & - $\quad$ Clay $(\%)$ & 47.2 & & \\
\hline & - Textural class & Clayey & & \\
\hline & - $\quad$ Bulk density $\left(\mathrm{g} \mathrm{cc}^{-1}\right)$ & 1.2 & Core sampler method & [29] \\
\hline & - $\quad$ Field capacity $(\%)$ & 32.4 & Field method & [30] \\
\hline & - $\quad$ Permanent wilting point $(\%)$ & 18.0 & Sunflower indicator method & [30] \\
\hline \multirow[t]{7}{*}{ II. } & Chemical properties & & & \\
\hline & - $\quad \mathrm{pH}$ (1:1.25 soil: water suspension) & 7.8 & $\mathrm{pH}$ meter & [28] \\
\hline & - $\quad$ EC (1:1.25 soil: water suspension) $\left(\mathrm{dS} \mathrm{m}^{-1}\right)$ & 0.2 & Conductivity bridge & [31] \\
\hline & - $\quad$ Organic carbon $(\%)$ & 0.6 & Walkey and Black's Wet oxidation method & [31] \\
\hline & - $\quad$ Available nitrogen $\left(\mathrm{N} \mathrm{kg} \mathrm{ha}^{-1}\right)$ & 320.3 & Alkaline permanganate method & [32] \\
\hline & - $\quad$ Available phosphorus $\left(\mathrm{P}_{2} \mathrm{O}_{5} \mathrm{~kg} \mathrm{ha}^{-1}\right)$ & 33.2 & Olsen's method & [31] \\
\hline & - $\quad$ Available potassium $\left(\mathrm{K}_{2} \mathrm{O} \mathrm{kg} \mathrm{ha}{ }^{-1}\right)$ & 426.5 & Neutral Normal $\mathrm{NH}_{4} \mathrm{OAC}$ extraction method & [31] \\
\hline
\end{tabular}

\subsection{Soil Moisture Measurement and Irrigation Scheduling}

The irrigation was scheduled as per the percent depletion of available soil moisture approach in maize under varied sowing methods through a Theta probe (MP 306 moisture sensor) as explained by [19]. The depth of the water supplied by irrigation and precipitation was taken into account for the total depth of the water applied to the treatments. The deficit irrigation was scheduled after 20 DAS in maize. The cowpea was grown on residual soil moisture without scheduling any irrigation during the rainy season. Observations of soil moisture content from 0 to $30 \mathrm{~cm}$ depth was recorded using the theta probe and expressed as a percent by volume. Later, the lateral soil wetting area in different treatments was recorded after $24 \mathrm{~h}$ of irrigation around the maize plants at 60 DAS and expressed in $\mathrm{cm}$ [33].

\subsection{Weeds Count, Moisture Content and Dry Weight}

Observations on weed flora, weed biomass, moisture content, and nutrient uptake were done at 30 and $60 \mathrm{DAS}$. The weeds were uprooted from $1 \times 1 \mathrm{~m}$ random quadrate in each treatment, and counted (No. $\mathrm{m}^{-2}$ ). However, in the Table 2 the dominant weed species in the experimental field are only quoted as monocots, dicots and sedges. For weed dry biomass $\left(\mathrm{g} \mathrm{m}^{-2}\right)$, the collected weeds were kept in an oven at $63^{\circ} \mathrm{C}$ till to get the 
constant weight [24]. The moisture content of the weeds was determined by subtracting the dry weight from the fresh weight, expressed as a percentage.

$$
\text { Moisture contentof weeds }(\%)=\left[\frac{\text { Fresh weight }(\mathrm{g})-\text { Dry weight }(\mathrm{g})}{\text { Dry weight }(\mathrm{g})}\right] \times 100
$$

Table 2. Important weed species reported at the experimental field.

\begin{tabular}{|c|c|c|}
\hline Weed Species & Common Name & Family \\
\hline \multicolumn{3}{|c|}{ Monocots (grasses) } \\
\hline Cynodon dactylon (L.) Pers. & Bermuda grass & Poaceae \\
\hline Digitaria marginata Link & Crabgrass & Poaceae \\
\hline Dinebra retroflexa Panzer & Viper grass & Poaceae \\
\hline Echinochloa crusgalli (L.) Beauv. & Watergrass & Poaceae \\
\hline Eleusine indica (L.) Gaertn. & Goosegrass & Poaceae \\
\hline Setaria italica $\mathrm{L}$. & Foxtail millet & Poaceae \\
\hline \multicolumn{3}{|c|}{ Dicots (broad leaved weeds; BL) } \\
\hline Ageratum conyzoides L. & Bill goat weed & Asteraceae \\
\hline Alternanthera sessilis L. & Sessile joyweed & Amaranthaceae \\
\hline Amaranthus viridis L. & Pigweed & Amaranthaceae \\
\hline Argemone mexicana L. & Mexican poppy & Papavaraceae \\
\hline Commelina benghalensis L. & Dayflower & Commelinaceae \\
\hline Convolvulus arvensis L. & Field bind weed & Convolvulaceae \\
\hline Corchorus olitorius L. & Jute mallow & Tiliaceae \\
\hline Desmodium diffusum DC. & Telegraphic plant & Leguminosae \\
\hline Malvastrum coromandelianum (L.) Garcke & Threelobe false mallow & Malvaceae \\
\hline Parthenium hysterophorus L. & Carrot weed & Asteraceae \\
\hline Phyllanthus niruri L. & Niruri & Euphorbiaceae \\
\hline Physalis minima $\mathrm{L}$. & Ground cherry & Solanaceae \\
\hline Portulaca oleracea L. & Purslane & Portulacaceae \\
\hline \multicolumn{3}{|c|}{ Sedges } \\
\hline Cyperus rotundus (L.) Palla & Purple nutsedge & Cyperaceae \\
\hline Cyperus iria (L.) & Umbrella sedge & Cyperaceae \\
\hline Cyperus esculentus (L.) & Yellow nut sedge & Cyperaceae \\
\hline
\end{tabular}

\subsection{Nutrient Uptake by Weeds}

The powdered weed samples were used for total $\mathrm{N}$ content estimation and determined using the micro Kjeldahl's method as described by [31]. A $0.5 \mathrm{~g}$ powder sample was pre-digested with $5 \mathrm{~mL}$ of concentrated $\mathrm{HNO}_{3}$ and digested with a di-acid mixture $\left(\mathrm{HNO}_{3}: \mathrm{HClO}_{4}\right.$ at 9:4). The volume of the digest was up to $100 \mathrm{~mL}$ distilled water and retained for total elemental analysis [31]. The same extract served to estimate $\mathrm{P}$ and $\mathrm{K}$. The total P content in the weeds was determined by measuring a known volume of the digested material using the Vanado-molybdate yellow colour method as described by [31] and expressed in percentage. Likewise, the total $\mathrm{K}$ content was estimated by atomizing the dilute digest into a calibrated flame photometer under appropriate measurement conditions, as described by [31] and expressed as a percentage. Later, nutrient uptake was determined by multiplying the amount of nutrients and biomass yield of weeds.

\subsection{Scoring of Insect Pests}

Scoring of pod borer (Maruca vitrata Fab. Syn. Maruca testulalis Geyer) in cowpea was undertaken during the pod formation stage by counting the number of damaged pods from 25 representative plants randomly in each plot and expressed in percentage.

$$
\text { Pod borer score }(\%)=\left[\frac{\text { Number of damaged pods }}{\text { Total number of pods }}\right] \times 100
$$




\subsection{Grain Yield and Maize Equivalent Yield (MEY) of Cowpea}

Twenty-five representative maize plants from each plot was harvested and the grains were separated after threshing, then dried, weighed, and expressed in $\mathrm{kg} \mathrm{ha}^{-1}$. Likewise, cowpea pods from 25 selected plants were harvested and threshed manually, then dried and weighed $\left(\mathrm{kg} \mathrm{ha}^{-1}\right)$. Subsequently, the grain yield of individual crops was expressed in terms of maize equivalent yield (MEY, $\mathrm{kg} \mathrm{ha}^{-1}$ ). MEY of cowpea was calculated according to the following formula [34].

$$
\operatorname{MEY}\left(\mathrm{kg} \mathrm{ha}^{-1}\right)=\text { Yield of maize }+ \text { Yield of cowpea }\left[\frac{\text { Price of cowpea }}{\text { Price of maize }}\right]
$$

\subsection{System Water-Use Efficiency (WUE)}

The system WUE was computed based on the system yield (MEY) and total water used in the cropping system.

$$
\text { System WUE }\left(\mathrm{kg} \mathrm{ha}-\mathrm{mm}^{-1}\right)=\frac{\operatorname{MEY}\left(\mathrm{kg} \mathrm{ha}^{-1}\right)}{\text { Total water used }(\mathrm{mm})}
$$

\subsection{Statistical Analysis}

The experimental data obtained at different growth stages of crop and weeds were compiled and subjected to statistical analysis by adopting Fischer's method of analysis of variance technique as outlined by [35]. The significance level used for the ' $\mathrm{F}$ ' test was $5 \%$. The significance was tested at a $5 \% \alpha$ level across all variables. The mean value of main plot, sub plot and interactions were separately subjected to the Duncan Multiple Range Test (DMRT) using the corresponding error mean sum of squares and degrees of freedom. The data pertaining to weeds (density and dry biomass) were subjected to square root transformation $\left[(x+1)^{1 / 2}\right]$ due to non-normality of data (verified using the Shapiro-Wilk test in SAS 9.3) as suggested by [36].

\section{Results and Discussion}

\subsection{Effect of Sowing Methods and Irrigation Levels on Weed Density in Maize}

Interaction effect of sowing methods and irrigation levels affected the weed density at 30 and 60 DAS (Table 3). However, individual effect of sowing methods and irrigation levels effects are only significant for 60 DAS. At 30 DAS, the sowing methods CF and RF had a higher density of monocots ( 2.98 and 2.80 No. $\mathrm{m}^{-2}$, respectively), dicot weeds ( 2.66 and 2.63 No. $\mathrm{m}^{-2}$, respectively) and sedges ( 2.15 and $2.09 \mathrm{No} . \mathrm{m}^{-2}$, respectively) compared to the BBF method $\left(2.64,2.36\right.$ and 1.94 No. $\mathrm{m}^{-2}$, respectively). The greater number of weeds (monocot; 2.95 No. $\mathrm{m}^{-2}$ and sedges; 2.25 No. $\mathrm{m}^{-2}$ ) was observed in irrigation at $\mathrm{I}_{40}$ and it was comparable with $\mathrm{I}_{50}$. However, $\mathrm{I}_{40}\left(2.76{\left.\mathrm{No} . \mathrm{m}^{-2}\right)}\right)$ and $\mathrm{I}_{50}\left(2.53{\left.\mathrm{No} . \mathrm{m}^{-2}\right)}^{-2}\right.$ differed significantly with respect to dicots density at 30 DAS. The lowest number of weeds (dicots and sedges) was observed with irrigation at $\mathrm{I}_{60}$ at 30 DAS (Table 3). At 60 DAS, a similar trend was also observed with respect to the number of weeds. Regarding the interaction effect of sowing methods and irrigation levels, regardless of weed flora, the RF and CF methods with irrigation at $\mathrm{I}_{40}$ and $\mathrm{I}_{50}$ recorded significantly higher and at par weed density followed by the combinations of RF and CF with irrigation at $\mathrm{I}_{10 \mathrm{D}}$ at 30 DAS. A similar trend was also reported at 60 DAS (Table 3). It was noted that the dicot weed density was comparatively higher at the 30 DAS compared to 60 DAS over monocot and sedges. As observed, the crop growth rate was faster after 30 DAS and peaked at 60 DAS, which could have surpassed the weed growth due to smothering and shading. We speculated further that the creation of a congenial microclimate with the RF method due to frequent irrigation might have allowed the weeds to emerge and grow vigorously. This may also be a result of the availability of soil moisture and nutrients for crops and weeds. These findings are similar to those of the [26] according to which excessive water application also allows weeds to grow. However, under the BBF method only the furrow portion was wetted and 
beds remained dry, which helps in reducing the wetting zone $(7.6 \mathrm{~cm})$ that could have decreased the weed seed germination and further growth. Similar findings was reported by [37] where the BBF method recorded significantly fewer weeds $\left(7.56 \mathrm{~m}^{-2}\right)$ compared to line sowing method $\left(11.58 \mathrm{~m}^{-2}\right)$. It is believed that weed density plays an important role in the depletion of available soil moisture and has significant negative effects on crop WUE as a result of increased competition. However, the competitiveness of different weed species at similar densities may not have the same influence on water use [38]. Therefore, sowing maize on $\mathrm{BBF}$ with irrigation at $\mathrm{I}_{40}$ and $\mathrm{I}_{50}$ reduces the weed germination and growth.

Table 3. Monocot, dicot and sedge density in maize as influenced by sowing methods and irrigation levels (pooled data of 2015 and 2016).

\begin{tabular}{|c|c|c|c|c|c|c|c|}
\hline \multirow{2}{*}{\multicolumn{2}{|c|}{ Treatments }} & \multicolumn{2}{|c|}{ Monocots (No. $\mathrm{m}^{-2}$ ) } & \multicolumn{2}{|c|}{ Dicots (No. $\mathrm{m}^{-2}$ ) } & \multicolumn{2}{|c|}{ Sedges (No. $\mathrm{m}^{-2}$ ) } \\
\hline & & 30 DAS & 60 DAS & 30 DAS & 60 DAS & 30 DAS & 60 DAS \\
\hline \multicolumn{8}{|c|}{ Sowing methods (L) } \\
\hline & & $2.64^{a, *}(6.63)$ & $2.02^{b}(4.63)$ & $2.36^{\mathrm{a}}(5.27)$ & $1.68^{b}(2.63)$ & $1.94^{\mathrm{a}}(3.73)$ & $1.85^{b}(3.29)$ \\
\hline & & $2.80^{\mathrm{a}}(7.33)$ & $2.33^{\mathrm{a}}(6.54)$ & $2.66^{\mathrm{a}}(6.97)$ & $2.13^{\mathrm{a}}(5.88)$ & $2.15^{\mathrm{a}}(4.38)$ & $2.00^{\mathrm{ab}}(4.79)$ \\
\hline & & $2.98^{\text {a }}(8.00)$ & $2.46^{\mathrm{a}}(7.75)$ & $2.63^{\mathrm{a}}(6.69)$ & $2.32^{\mathrm{a}}(6.54)$ & $2.09^{\mathrm{a}}(3.98)$ & $2.29^{\mathrm{a}}(6.33)$ \\
\hline & & 0.10 & 0.02 & 0.10 & 0.04 & 0.08 & 0.05 \\
\hline \multicolumn{8}{|c|}{ Irrigation levels (I) } \\
\hline & & $2.74^{\mathrm{a}}(7.22)$ & $2.24^{\mathrm{b}}(6.28)$ & $2.53^{\mathrm{b}}(6.03)$ & $1.94^{\mathrm{b}}(4.22)$ & 1.99 bc (3.75) & $2.00^{\mathrm{a}}(4.17)$ \\
\hline & & $2.95^{\mathrm{a}}(8.39)$ & $2.44^{\mathrm{a}}(7.11)$ & $2.76^{\mathrm{a}}(7.37)$ & $2.28^{a}(6.28)$ & $2.25^{\mathrm{a}}(4.72)$ & $2.20^{\mathrm{a}}(5.28)$ \\
\hline & & $2.87^{\text {a }}(7.89)$ & $2.37^{\mathrm{ab}}(6.83)$ & $2.53^{b}(6.29)$ & $2.17^{\text {a }}(5.39)$ & $2.22^{\mathrm{ab}}(4.62)$ & $2.12^{\text {a }}(5.39)$ \\
\hline & & $2.66^{\mathrm{a}}(6.83)$ & $2.03^{c}(5.00)$ & $2.40^{\mathrm{b}}(5.55)$ & $1.79^{\mathrm{b}}(4.17)$ & $1.86^{\mathrm{c}}(3.02)$ & $1.86^{\mathrm{b}}(4.39)$ \\
\hline & & 0.10 & 0.05 & 0.07 & 0.06 & 0.08 & 0.05 \\
\hline \multicolumn{8}{|c|}{ Interaction $(\mathrm{I} \times \mathrm{L})$} \\
\hline \multirow[t]{4}{*}{ BBF } & $\mathrm{I}_{10 \mathrm{D}}$ & $2.57^{b c}(6.33)$ & $1.98^{\mathrm{c}}(4.17)$ & $2.30^{\mathrm{cd}}(4.85)$ & $1.64^{\mathrm{gh}}(2.33)$ & $1.85^{b c}(3.33)$ & $1.81^{\text {de }}(3.00)$ \\
\hline & $\mathrm{I}_{40}$ & $2.66^{\mathrm{a}-\mathrm{c}}(6.67)$ & $2.30^{\mathrm{ab}}(6.00)$ & $2.67^{\mathrm{a}-\mathrm{c}}(6.73)$ & $1.86^{\mathrm{e}-\mathrm{g}}(3.33)$ & $2.17^{\mathrm{a}-\mathrm{c}}(4.37)$ & $1.99^{b-e}(3.67)$ \\
\hline & $\mathrm{I}_{50}$ & $3.00^{\mathrm{ab}}(8.50)$ & $2.24^{\mathrm{bc}}(5.67)$ & $2.36^{\mathrm{b}-\mathrm{d}}(5.35)$ & $1.70^{\mathrm{f}-\mathrm{h}}(2.67)$ & $2.20^{\mathrm{a}-\mathrm{c}}(4.44)$ & $1.90^{\mathrm{c}-\mathrm{e}}(3.50)$ \\
\hline & $\mathrm{I}_{60}$ & $2.32^{\mathrm{c}}(5.00)$ & $1.58^{\mathrm{d}}(2.67)$ & $2.11^{\mathrm{d}}(4.16)$ & $1.52^{\mathrm{h}}(2.17)$ & $1.76^{\mathrm{c}}(2.63)$ & $1.69 \mathrm{e}(3.00)$ \\
\hline \multirow[t]{4}{*}{$\mathrm{CF}$} & $\mathrm{I}_{10 \mathrm{D}}$ & $2.64^{\mathrm{a}-\mathrm{c}}(6.67)$ & $2.19^{b c}(6.17)$ & $2.57^{\mathrm{a}-\mathrm{c}}(6.20)$ & $2.01^{\text {de }}(5.00)$ & $2.21^{\mathrm{a}-\mathrm{c}}(4.71)$ & $1.91^{\mathrm{c}-\mathrm{e}}(3.83)$ \\
\hline & $\mathrm{I}_{40}$ & $2.99^{a b}(8.67)$ & $2.46^{\mathrm{ab}}(7.00)$ & $2.61^{\mathrm{a}-\mathrm{c}}(6.49)$ & $2.37^{a-c}(7.33)$ & $2.24^{\mathrm{a}-\mathrm{c}}(4.57)$ & $2.15^{\mathrm{a}-\mathrm{d}}(5.33)$ \\
\hline & $\mathrm{I}_{50}$ & $2.80^{\mathrm{a}-\mathrm{c}}(7.50)$ & $2.48^{\mathrm{ab}}(7.50)$ & $2.77^{\mathrm{ab}}(7.80)$ & $2.27^{\mathrm{b}-\mathrm{d}}(6.67)$ & $2.29 \mathrm{ab}(4.94)$ & $2.12^{\mathrm{a}-\mathrm{d}}(5.50)$ \\
\hline & $\mathrm{I}_{60}$ & $2.77^{\mathrm{a}-\mathrm{c}}(7.33)$ & $2.18^{b c}(5.50)$ & $2.32^{\mathrm{cd}}(4.97)$ & $1.87^{\mathrm{e}-\mathrm{g}}(4.50)$ & $1.79^{\text {c }}(2.78)$ & $1.83^{\text {de }}(4.50)$ \\
\hline \multirow[t]{5}{*}{ RF } & $\mathrm{I}_{10 \mathrm{D}}$ & $2.82^{\mathrm{a}-\mathrm{c}}(7.67)$ & $2.55^{\mathrm{a}}(8.50)$ & $2.45^{\mathrm{a}-\mathrm{d}}(5.70)$ & $2.16^{\mathrm{c}-\mathrm{e}}(5.33)$ & $1.92^{\mathrm{a}-\mathrm{c}}(3.20)$ & $2.29^{\mathrm{a}-\mathrm{c}}(5.67)$ \\
\hline & $\mathrm{I}_{40}$ & $3.19^{\mathrm{a}}(9.83)$ & $2.57^{\mathrm{a}}(8.33)$ & $2.99^{\mathrm{a}}(8.89)$ & $2.60^{\mathrm{a}}(8.17)$ & $2.36^{\mathrm{a}}(5.23)$ & $2.47^{\mathrm{a}}(6.83)$ \\
\hline & $\mathrm{I}_{50}$ & $3.02^{a b}(8.83)$ & $2.39^{a b}(7.33)$ & $2.71^{\mathrm{a}-\mathrm{c}}(7.03)$ & $2.54^{\mathrm{ab}}(6.83)$ & $2.18^{\mathrm{a}-\mathrm{c}}(4.50)$ & $2.35^{\mathrm{ab}}(7.17)$ \\
\hline & $\mathrm{I}_{60}$ & $2.89^{\mathrm{a}-\mathrm{c}}(8.00)$ & $2.33^{\mathrm{ab}}(6.83)$ & $2.76^{\mathrm{ab}}(7.51)$ & $1.99^{\mathrm{d}-\mathrm{f}}(5.83)$ & $2.02^{\mathrm{a}-\mathrm{c}}(3.65)$ & $2.06^{\mathrm{a}-\mathrm{e}}(5.67)$ \\
\hline & & 0.17 & 0.09 & 0.13 & 0.10 & 0.14 & 0.08 \\
\hline
\end{tabular}

* Data are transformed by using square root transformation $(\sqrt{ } x+0.5)$ and figures in parenthesis indicate original value, Means followed by the same letter (s) within a column are not significantly differed by DMRT (Duncan's multiple range test) $(p=0.05)$; BBF, broad bed and furrow; $\mathrm{CF}$, corrugated furrow (shallow); DAS, days after sowing; RF, ridges and furrow; $\mathrm{I}_{1 \mathrm{OD}}$, irrigation once in 10 days; $\mathrm{I}_{40}$, irrigation at $40 \%$ depletion; $\mathrm{I}_{50}$, irrigation at $50 \%$ depletion; and $\mathrm{I}_{60}$, irrigation at $60 \%$ depletion.

\subsection{Weed Dry Weight in Maize}

Regardless of the effect of treatment, in general, dicot weeds showed higher dry biomass, followed by grasses and sedges at 30 and 60 DAS under both CF and RF methods of sowing. Compared to CF and BBF, significantly greater weed dry weight (monocots; 8.04-19.8\%, dicots; $12.86-26 \%$ and sedges; $8.69-32.18 \%$ ) was noticed in the RF method of sowing at 30 DAS. The dry weight of weeds also seems to follow the same trend at 60 DAS (Table 4). Among irrigation levels, $\mathrm{I}_{40}$ had the highest weed dry weight (monocots; $3.16 \mathrm{~g} \mathrm{~m}^{-2}$, dicots; $3.21 \mathrm{~g} \mathrm{~m}^{-2}$ and sedges; $2.13 \mathrm{~g} \mathrm{~m}^{-2}$ ) followed by irrigation at $\mathrm{I}_{50}$. The lowest weed dry weight was observed with irrigation at $\mathrm{I}_{60}$ (monocots; $2.57 \mathrm{~g} \mathrm{~m}^{-2}$, dicots; $2.47 \mathrm{~g} \mathrm{~m}^{-2}$ and sedges; $1.92 \mathrm{~g} \mathrm{~m}^{-2}$ ) at $30 \mathrm{DAS}$. Regarding the interaction effect, greater dry weight of monocot (3.20-45.18\%), dicot (2.7-48.34\%) and sedge weeds (15.09-44.52) was observed with $\mathrm{RF}+\mathrm{I}_{40}$ and $\mathrm{RF}+\mathrm{I}_{50}$. The lowest dry weight of monocot $\left(1.88 \mathrm{~g} \mathrm{~m}^{-2}\right)$, dicot $\left(1.87 \mathrm{~g} \mathrm{~m}^{-2}\right)$ and sedge $\left(1.47 \mathrm{~g} \mathrm{~m}^{-2}\right)$ weeds was recorded in BBF $+\mathrm{I}_{60}$ at 30 DAS 
(Table 4). It was found that irrespective of weed flora, dry matter was reduced with reduced wetting zone due to increased irrigation interval (Table 4). A lower moisture regime may have reduced the moisture uptake of weeds. Higher uptake of moisture and nutrients by weeds due to short duration could assimilate more photosynthates, resulting in increased biomass production. The higher wetting area with RF $(11.70 \mathrm{~cm})$ and $C F(10.10 \mathrm{~cm})$ could have created an environment conducive to the growth of weeds (Table 5). This is in line with [39]. The favourable micro-climate in terms of higher wetting area and lower canopy temperature could result in higher weed growth. The higher dry weight of BL weeds can be attributed to greater diversity and vigorous branching patterns compared to grasses and sedges. $\mathrm{BBF}+\mathrm{I}_{60}$ (irrigation at higher depletion) could have created partial moisture stress and, as a result, reduced the wetting zone $(6.10 \mathrm{~cm})$, which affected weed emergence and proliferation. The authors assumed that the rough, dry soil surface under the BBF method due to limited furrow irrigation could discourage or delay germination, emergence and subsequent weed growth. Reduced weeds dry matter may be attributed to the reduced moisture availability [38]. Similar outcomes were reported by [37] on alluvial soils where the BBF sowing method found the lowest weed density $\left(14.0 \mathrm{No}^{-2}\right)$ and dry matter $\left(3.76 \mathrm{~g} \mathrm{~m}^{-2}\right)$ at 60 DAS. Therefore, the present study indicates that the dry weight accumulation of weeds increases with increased soil moisture availability and wetting area.

Table 4. Dry weight of monocot, dicot and sedge weeds as influenced by sowing methods and irrigation levels in maize (pooled data of 2015 and 2016).

\begin{tabular}{|c|c|c|c|c|c|c|c|}
\hline \multirow{2}{*}{\multicolumn{2}{|c|}{ Treatments }} & \multicolumn{2}{|c|}{ Monocots $\left(\mathrm{g} \mathrm{m}^{-2}\right.$ ) } & \multicolumn{2}{|c|}{ Dicots $\left(\mathrm{g} \mathrm{m}^{-2}\right)$} & \multicolumn{2}{|c|}{ Sedges $\left(\mathrm{g} \mathrm{m}^{-2}\right)$} \\
\hline & & 30 DAS & 60 DAS & 30 DAS & 60 DAS & 30 DAS & 60 DAS \\
\hline \multicolumn{8}{|c|}{ Sowing methods (L) } \\
\hline & BBF & $2.57^{c, *}(6.30)$ & $1.37^{\mathrm{b}}(1.95)$ & $2.51^{\mathrm{c}}(6.06)$ & $1.33^{\mathrm{c}}(1.39)$ & $1.74^{\mathrm{b}}(2.61)$ & $1.42^{\mathrm{b}}(1.71)$ \\
\hline & $\mathrm{CF}$ & $2.97^{\mathrm{b}}(8.37)$ & $1.60^{\mathrm{b}}(3.28)$ & $2.98^{\mathrm{b}}(8.50)$ & $1.64^{\mathrm{b}}(4.23)$ & $2.10^{\mathrm{b}}(3.96)$ & $1.51^{\mathrm{b}}(2.67)$ \\
\hline & RF & $3.23^{\mathrm{a}}(10.02)$ & $1.86^{\mathrm{a}}(4.09)$ & $3.42^{\mathrm{a}}(11.27)$ & $1.87^{\mathrm{a}}(5.28)$ & $2.30^{\mathrm{a}}(4.91)$ & $1.70^{\mathrm{a}}(3.89)$ \\
\hline & S.Em. \pm & 0.02 & 0.03 & 0.03 & 0.05 & 0.06 & 0.02 \\
\hline \multicolumn{8}{|c|}{ Irrigation levels (I) } \\
\hline & $\mathbf{I}_{10 \mathrm{D}}$ & $2.97^{\mathrm{b}}(8.49)$ & $1.67^{\mathrm{a}}(3.23)$ & $3.03^{b}(8.89)$ & $1.48^{\mathrm{c}}(2.85)$ & $1.91^{\mathrm{b}}(3.26)$ & $1.54^{\mathrm{a}}(2.47)$ \\
\hline & $\mathrm{I}_{40}$ & $3.16^{\mathrm{a}}(9.54)$ & $1.72^{\mathrm{a}}(3.78)$ & $3.21^{\mathrm{a}}(9.93)$ & $1.75^{\mathrm{a}}(4.53)$ & $2.13^{\mathrm{a}}(4.10)$ & $1.64^{\mathrm{a}}(3.30)$ \\
\hline & $\mathbf{I}_{50}$ & $3.00^{b}(8.54)$ & $1.71^{\mathrm{a}}(3.34)$ & $3.17^{a b}(9.77)$ & $1.56^{\text {bc }}(3.79)$ & $2.24^{\mathrm{a}}(4.65)$ & $1.55^{\mathrm{a}}(3.03)$ \\
\hline & $I_{60}$ & $2.57^{\mathrm{c}}(6.35)$ & $1.48^{\mathrm{b}}(2.08)$ & $2.47^{\mathrm{c}}(5.85)$ & $1.65^{\mathrm{b}}(3.37)$ & $1.92^{b}(3.30)$ & $1.43^{b}(2.21)$ \\
\hline & S.Em. \pm & 0.04 & 0.06 & 0.05 & 0.03 & 0.04 & 0.04 \\
\hline \multicolumn{8}{|c|}{ Interaction $(\mathrm{I} \times \mathrm{L})$} \\
\hline \multirow[t]{4}{*}{ BBF } & $\mathrm{I}_{10 \mathrm{D}}$ & $2.62^{d}(6.39)$ & $1.22^{\mathrm{c}}(1.23)$ & $2.56^{\mathrm{e}}(6.06)$ & $1.29^{\mathrm{d}}(1.27)$ & $1.68^{\mathrm{d}}(2.36)$ & $1.41^{\mathrm{cd}}(1.55)$ \\
\hline & $\mathrm{I}_{40}$ & $2.98^{c}(8.39)$ & $1.61^{\mathrm{ab}}(3.26)$ & $2.86^{\mathrm{cd}}(7.73)$ & $1.36^{\mathrm{d}}(1.59)$ & $1.94^{\mathrm{c}}(3.36)$ & $1.51^{\mathrm{bc}}(2.07)$ \\
\hline & $\mathrm{I}_{50}$ & $2.80^{\mathrm{c}}(7.39)$ & $1.58^{\mathrm{b}}(2.55)$ & $2.77^{\mathrm{c}-\mathrm{e}}(7.39)$ & $1.37^{\mathrm{d}}(1.57)$ & $1.86^{\mathrm{cd}}(3.02)$ & $1.47^{\mathrm{b}-\mathrm{d}}(1.87)$ \\
\hline & $\mathrm{I}_{60}$ & $1.88^{\mathrm{e}}(3.05)$ & $1.07^{\mathrm{c}}(0.78)$ & $1.87^{\mathrm{f}}(3.06)$ & $1.29^{\mathrm{d}}(1.13)$ & $1.47^{\mathrm{e}}(1.69)$ & $1.27^{\mathrm{d}}(1.34)$ \\
\hline \multirow[t]{4}{*}{$\mathrm{CF}$} & $\mathrm{I}_{10 \mathrm{D}}$ & $2.86^{\mathrm{c}}(7.72)$ & $1.90^{\mathrm{ab}}(4.62)$ & $3.01^{b c}(8.73)$ & $1.46^{\mathrm{cd}}(3.27)$ & $1.96^{\mathrm{c}}(3.36)$ & $1.55^{\mathrm{bc}}(2.35)$ \\
\hline & $\mathrm{I}_{40}$ & $3.19^{b}(9.72)$ & $1.64^{\mathrm{ab}}(3.47)$ & $3.16^{\mathrm{b}}(9.49)$ & $1.63^{b c}(4.61)$ & $2.20^{b}(4.36)$ & 1.49 bc (2.96) \\
\hline & $\mathrm{I}_{50}$ & $2.98^{c}(8.39)$ & $1.65^{\mathrm{ab}}(3.03)$ & $3.13^{b}(9.33)$ & $1.78^{\mathrm{b}}(5.17)$ & $2.20^{\mathrm{b}}(4.39)$ & $1.52^{b c}(3.19)$ \\
\hline & $\mathrm{I}_{60}$ & $2.85^{\mathrm{c}}(7.65)$ & $1.57^{\mathrm{b}}(2.29)$ & $2.63^{\text {de }}(6.46)$ & $1.68^{b}(3.88)$ & $2.05^{b c}(3.72)$ & $1.46^{\mathrm{b}-\mathrm{d}}(2.16)$ \\
\hline \multirow[t]{5}{*}{ RF } & $\mathrm{I}_{10 \mathrm{D}}$ & $3.21^{b}(9.85)$ & $1.86^{\mathrm{ab}}(4.12)$ & $3.52^{\mathrm{a}}(11.89)$ & $1.70^{b}(4.01)$ & $2.08^{b c}(4.06)$ & $1.65^{\mathrm{b}}(4.05)$ \\
\hline & $\mathrm{I}_{40}$ & $3.43^{\mathrm{a}}(11.35)$ & $1.94^{\mathrm{a}}(4.33)$ & $3.62^{\mathrm{a}}(12.59)$ & $2.11^{\mathrm{a}}(6.86)$ & $2.65^{\mathrm{a}}(6.52)$ & $1.92^{\mathrm{a}}(4.85)$ \\
\hline & $\mathrm{I}_{50}$ & $3.32^{\mathrm{ab}}(10.52)$ & $1.91^{\mathrm{ab}}(4.45)$ & $3.61^{\mathrm{a}}(12.58)$ & $1.97^{\mathrm{a}}(5.08)$ & $2.25^{\mathrm{b}}(4.59)$ & $1.66^{b}(3.52)$ \\
\hline & $\mathrm{I}_{60}$ & $2.97^{\mathrm{c}}(8.35)$ & $1.79 \mathrm{ab}(3.18)$ & $2.92^{b c}(8.03)$ & $1.70^{b}(5.18)$ & $2.22^{b}(4.49)$ & $1.55^{b c}(3.13)$ \\
\hline & S.Em. \pm & 0.06 & 0.10 & 0.08 & 0.06 & 0.07 & 0.06 \\
\hline
\end{tabular}

* Data is transformed by using square root transformation $(\sqrt{ } x+0.5)$ and figures in parenthesis indicate original value; Means followed by the same letter (s) within a column are not significantly differed by DMRT ( $p=0.05)$; BBF, broad bed and furrow; CF, corrugated furrow (shallow); RF, ridges and furrow; $\mathrm{I}_{1 \mathrm{OD}}$, irrigation once in 10 days; $\mathrm{I}_{40}$, irrigation at $40 \%$ depletion; $\mathrm{I}_{50}$, irrigation at $50 \%$ depletion; and $\mathrm{I}_{60}$, irrigation at $60 \%$ depletion. 
Table 5. Moisture content of weeds, soil and lateral wetting zone in maize influenced by sowing methods and irrigation levels (pooled data of 2015 and 2016).

\begin{tabular}{|c|c|c|c|c|c|c|}
\hline \multirow{2}{*}{\multicolumn{2}{|c|}{ Treatments }} & \multicolumn{2}{|c|}{ Weeds Moisture Content (\%) } & \multicolumn{2}{|c|}{ Soil Moisture Content (\%) } & \multirow{2}{*}{$\begin{array}{c}\text { Soil Wetting Zone }(\mathrm{cm}) \\
60 \text { DAS }\end{array}$} \\
\hline & & 30 DAS & 60 DAS & 30 DAS & 60 DAS & \\
\hline \multicolumn{7}{|c|}{ Sowing methods (L) } \\
\hline & & $67.50^{\mathrm{c}}$ & $68.3^{b}$ & $28.27^{\mathrm{b}}$ & $26.37^{b}$ & $7.6^{\mathrm{c}}$ \\
\hline & & $72.18^{b}$ & $75.6^{\mathrm{a}}$ & $30.68^{a b}$ & $28.00^{\mathrm{a}}$ & $10.1^{b}$ \\
\hline & & $78.10^{\mathrm{a}}$ & $79.6^{\mathrm{a}}$ & $32.99^{a}$ & $30.81^{a b}$ & $11.7^{\mathrm{a}}$ \\
\hline & & 0.68 & 1.40 & 0.11 & 0.25 & 0.12 \\
\hline \multicolumn{7}{|c|}{ Irrigation levels (I) } \\
\hline & & $69.67^{b}$ & $74.3^{\mathrm{ab}}$ & $31.06^{\mathrm{b}}$ & $29.47^{c}$ & $9.1^{\mathrm{b}}$ \\
\hline & & $76.75^{a}$ & $77.3^{\mathrm{a}}$ & $34.22^{\mathrm{a}}$ & $32.96^{\mathrm{b}}$ & $10.8^{\mathrm{a}}$ \\
\hline & & $75.53^{\mathrm{a}}$ & $75.5^{\mathrm{a}}$ & $32.13^{\mathrm{a}}$ & $30.95^{\mathrm{a}}$ & $10.4^{\mathrm{ab}}$ \\
\hline & & $68.42^{b}$ & $70.8^{b}$ & $30.18^{b}$ & $26.84^{b c}$ & $8.9^{b}$ \\
\hline & & 0.56 & 1.46 & 0.10 & 0.13 & 0.19 \\
\hline \multicolumn{7}{|c|}{ Interaction $(\mathrm{I} \times \mathrm{L})$} \\
\hline \multirow[t]{4}{*}{ BBF } & $\mathrm{I}_{10 \mathrm{D}}$ & $64.71 \mathrm{~g}$ & 67.0 de & $30.74^{\mathrm{h}}$ & $28.57^{\mathrm{e}}$ & $6.5^{\mathrm{e}}$ \\
\hline & $\mathrm{I}_{40}$ & $70.34^{\mathrm{d}-\mathrm{f}}$ & $71.6^{\mathrm{cd}}$ & $31.90^{\mathrm{b}-\mathrm{e}}$ & $30.23^{d}$ & $9.0^{\mathrm{d}}$ \\
\hline & $\mathrm{I}_{50}$ & $72.39^{c-e}$ & $72.1^{\mathrm{b}-\mathrm{d}}$ & $31.74^{\mathrm{c}-\mathrm{f}}$ & $30.26^{b c}$ & $8.8^{\mathrm{d}}$ \\
\hline & $\mathrm{I}_{60}$ & $62.56^{\mathrm{g}}$ & $62.4^{\mathrm{e}}$ & $26.69^{h}$ & $25.41^{\mathrm{d}}$ & $6.1^{\mathrm{e}}$ \\
\hline \multirow[t]{4}{*}{ CF } & $\mathrm{I}_{10 \mathrm{D}}$ & $68.57^{\mathrm{f}}$ & $75.7^{a-c}$ & $31.08 \mathrm{gh}$ & $29.27^{\mathrm{d}}$ & $9.2^{\mathrm{d}}$ \\
\hline & $\mathrm{I}_{40}$ & $74.47^{b c}$ & $74.7^{\mathrm{a}-\mathrm{d}}$ & $33.27^{a-c}$ & $32.81^{\mathrm{cd}}$ & $10.8^{b c}$ \\
\hline & $\mathrm{I}_{50}$ & $75.92^{b}$ & $78.6^{a-c}$ & $32.19^{a-d}$ & $32.32^{a}$ & $10.5^{b c}$ \\
\hline & $\mathrm{I}_{60}$ & 69.78 ef & $73.5^{a-d}$ & $30.19^{\mathrm{f}-\mathrm{h}}$ & $29.59 \mathrm{~cd}$ & $9.9 \mathrm{~cd}$ \\
\hline \multirow[t]{4}{*}{$\mathbf{R F}$} & $\mathrm{I}_{10 \mathrm{D}}$ & $75.75^{b}$ & $80.1^{a b}$ & $31.35^{\mathrm{e}-\mathrm{g}}$ & $30.58^{b}$ & $11.5^{\mathrm{ab}}$ \\
\hline & $\mathrm{I}_{40}$ & $81.95^{a}$ & $81.2^{\mathrm{a}}$ & $34.48^{\mathrm{a}}$ & $34.28^{\mathrm{a}}$ & $12.5^{\mathrm{a}}$ \\
\hline & $\mathrm{I}_{50}$ & $81.77^{a}$ & $80.3^{a b}$ & $33.45^{\mathrm{ab}}$ & $32.85^{\mathrm{ab}}$ & $11.9^{\mathrm{a}}$ \\
\hline & $\mathrm{I}_{60}$ & $72.92 \mathrm{~cd}$ & $76.6^{a-c}$ & $30.66^{\mathrm{d}-\mathrm{f}}$ & $30.52^{b}$ & $10.8^{b c}$ \\
\hline \multicolumn{2}{|c|}{ S.Em. \pm} & 0.98 & 2.53 & 0.18 & 0.22 & 0.34 \\
\hline
\end{tabular}

Means followed by the same letter (s) within a column are not significantly differed by DMRT ( $p=0.05$ ); BBF, broad bed and furrow; CF, corrugated furrow (shallow); $\mathrm{RF}$, ridges and furrow; $\mathrm{I}_{1 \mathrm{OD}}$, irrigation once in 10 days; $\mathrm{I}_{40}$, irrigation at $40 \%$ depletion; $\mathrm{I}_{50}$, irrigation at $50 \%$ depletion; and $\mathrm{I}_{60}$, irrigation at $60 \%$ depletion.

\subsection{Weed Moisture Content and Soil Wetting Zone}

The moisture content of weeds at both 30 and 60 DAS was greater with the RF $(78.10 \%$ and $79.6 \%$ respectively, ) method than the CF $(72.18 \%$ and $75.6 \%$ respectively, $)$ and BBF $(67.50 \%$ and $68.3 \%$ respectively) methods of sowing (Table 5). The weeds had higher moisture uptake under irrigation at lower $\left(\mathrm{I}_{40}\right)$ and moderate $\left(\mathrm{I}_{50}\right)$ depletion at 30 DAS (75.53-76.75\%) and 60 DAS (75.50-77.30\%) compared to irrigation at higher depletion $\left(\mathrm{I}_{60}\right.$, $68.42 \%$ at 30 DAS and $70.80 \%$ at 60 DAS). An increased moisture content of weeds was recorded as a result of higher soil moisture content at 30 DAS $(32.99 \%)$ and at 60 DAS (30.81\%) under the RF method followed by CF and BBF (Table 5). Likewise, irrigation at lower and moderate depletion $\left(\mathrm{I}_{40}\right.$ and $\left.\mathrm{I}_{50}\right)$ maintained the higher and on par soil moisture (30.68-32.99\% to $28.00-30.81 \%)$ at 30 and 60 DAS, respectively, over $\mathrm{I}_{10 \mathrm{D}}(29.47-31.065)$ and $\mathrm{I}_{60}(26.84-30.18 \%)$. Regarding the interaction effect, $\mathrm{RF}+\mathrm{I}_{40}$ and $\mathrm{I}_{50}$ and $\mathrm{CF}+\mathrm{I}_{40}$ and $\mathrm{I}_{50}$ maintained the higher soil moisture at both 30 and $60 \mathrm{DAS}$ compared to $\mathrm{BBF}+\mathrm{I}_{60}$. The authors presume that the higher total water usage under RF method $+\mathrm{I}_{40}$ and $\mathrm{I}_{50}$ (889.6-816.6 mm, i.e., $25.17-33.38 \%$ higher) over $\mathrm{BBF}+\mathrm{I}_{60}$ may be the reason for the excess soil wetting zone. Along these lines, [25] found that the overall dry weight of weeds was strongly influenced by water stress. Furthermore, this study opined that reduced application of irrigation from $100 \%$ to $40 \%$ of crop evapotranspiration decreased the total dry weight of weeds by $25.66 \%$ and $25.71 \%$ after 70 and 110 days after sowing in peanut, respectively, on a sandy loam soils of Egypt. This was primarily a result of reduced soil moisture availability and subsequent weed uptake. However, such reports on the impact of sowing methods and irrigation levels on weed moisture content are limited. Higher soil moisture content has obviously contributed to the vigorous growth of weeds and the 
accumulation of biomass through a higher transpiration coefficient. Therefore, it is evident from the present investigation that modification in sowing methods and irrigation water application has a considerable effect on the moisture content of soil and weeds in maize due to the altered lateral wetting zone and water application.

\subsection{N, P and K Uptake of Weeds in Maize}

N, P and K uptake of weeds was significantly influenced by the interaction of methods and irrigation levels (Figure 1) in the maize-cowpea system at the tasselling stage of maize. Across the sowing methods and irrigation levels, the uptake of $\mathrm{N}$ and $\mathrm{K}$ was nearly similar but it was almost four times higher than the uptake of $\mathrm{P}$ by weeds. In this study, the RF method recorded a greater $\mathrm{N}\left(71.78 \mathrm{~kg} \mathrm{ha}^{-1}\right), \mathrm{P}\left(14.19 \mathrm{~kg} \mathrm{ha}^{-1}\right)$ and $\mathrm{K}$ $\left(6.26 \mathrm{~kg} \mathrm{ha}^{-1}\right)$ uptake of weeds followed by the CF and BBF methods. Similarly, among the irrigation levels, irrigation at $\mathrm{I}_{10 \mathrm{D}}$ and $\mathrm{I}_{50}$ recorded a higher $\mathrm{N}\left(65.51-65.97 \mathrm{~kg} \mathrm{ha}^{-1}\right), \mathrm{P}$ (13.07-13.18 kg ha-1) and $\mathrm{K}\left(62.16-62.53 \mathrm{~kg} \mathrm{ha}^{-1}\right)$ uptake of weeds. The lowest uptake of $\mathrm{N}\left(62.45 \mathrm{~kg} \mathrm{ha}^{-1}\right), \mathrm{P}\left(13.07 \mathrm{~kg} \mathrm{ha}^{-1}\right)$ and $\mathrm{K}\left(55.23 \mathrm{~kg} \mathrm{ha}^{-1}\right)$ was recorded in $\mathrm{I}_{60}$ over other irrigation levels (Figure 1). With respect to interaction effect, $\mathrm{RF}+\mathrm{I}_{10 \mathrm{D}}$ had a higher uptake of $\mathrm{N}\left(74.76 \mathrm{~kg} \mathrm{ha}^{-1}\right), \mathrm{P}\left(15.34 \mathrm{~kg} \mathrm{ha}^{-1}\right)$ and $\mathrm{K}\left(70.57 \mathrm{~kg} \mathrm{ha}^{-1}\right)$ followed by RF $+\mathrm{I}_{50}$. It is known that the uptake of nutrients from a plant is dependent on its uptake ability and the availability of nutrients in the soil. The availability of nutrients is primarily dependent on the physical and chemical properties of the soil for nutrient transformation. In this study, the RF method plus $\mathrm{I}_{50}$ maintained the optimal soil moisture regime, aeration and lower canopy temperature. Thus, enhanced the uptake of N, P and K due to higher light interception, total biomass and favourable rhizosphere environment, secretion of root exudates and better nutrient transformation [20,40]. The higher degree of water stress in $\mathrm{BBF}+\mathrm{I}_{60}$ can lead to poor nutrient mineralization and poor microbial activity [41]. The lower uptake of $\mathrm{N}, \mathrm{P}$ and $\mathrm{K}$ in $\mathrm{BBF}+\mathrm{I}_{60}$ may have been due to the lower dry weight of the weeds. However, $\mathrm{I}_{10 \mathrm{D}}$ recorded a lower weed dry weight but managed to accumulate higher $\mathrm{N}, \mathrm{P}$ and $\mathrm{K}$ in weeds, this was probably due to higher nutrient concentration as a result of certain degree of moisture stress. Therefore, $\mathrm{RF}$ under moderate moisture stress $\left(\mathrm{I}_{10 \mathrm{D}}\right.$ and $\mathrm{I}_{50}$ ) favoured the nutrient $(\mathrm{N}, \mathrm{P}$ and $\mathrm{K}$ ) uptake of weeds in the maize-cowpea system.

\subsection{Weeds Dry Weight, Soil Moisture Content and Incidence of Pod Borer in Cowpea}

Different sowing methods exhibited a significant effect on weed dry weight in cowpea at 55 DAS (Table 6). The BBF sowing method resulted in the highest dry weight of weeds $\left(2.81 \mathrm{~g} \mathrm{~m}^{-2}\right)$, followed by RF $\left(2.57 \mathrm{~g} \mathrm{~m}^{-2}\right)$. In contrast, the CF sowing method had a significantly lower dry weight of weeds $\left(2.41 \mathrm{~g} \mathrm{~m}^{-2}\right)$. It was observed that BBF recorded a higher soil moisture content (29.27\%) followed by RF (27.20\%) and CF methods (26.31\%) due to increased storage of rain water (Table 6). Meanwhile, the higher incidence of pod borer was reported in the BBF sowing method (32.08\%) at 65 DAS followed by RF (28.83\%) and CF methods (25.63\%). The higher incidence of pod borer in the BBF method could be due to the result of higher soil moisture and weed density, which might have sheltered the larvae of the pod borer due to the shading or cooling effect. The similar finding was reported by [42] wherein higher soil moisture in chickpea (Cicer arietinum L.) increased pod borer (Helicoverpa armigera, Hubner) incidence due to vigorous growth of chickpea. The increased weed dry weight in the BBF method might be ascribed to increase in situ moisture conservation and lack of water stagnation due to wider furrows. This might have improved the root growth and nutrient accessibility of the crop and weeds [20,43]. Thus, higher soil moisture under the BBF method may favour the cowpea and weed growth with higher incidence of pod borer. 

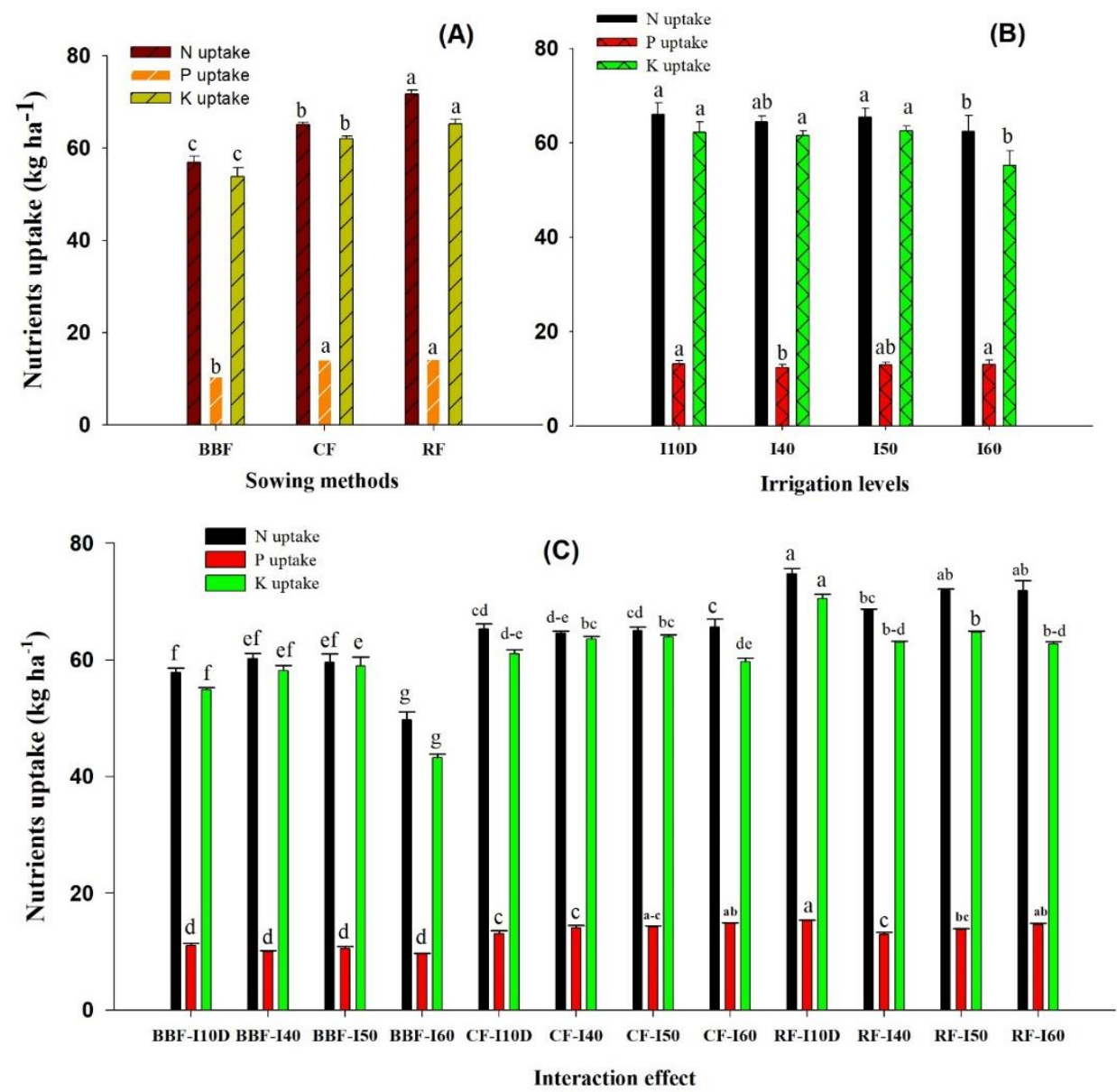

Figure 1. N, P and K uptake of weeds as influenced by sowing methods (A), irrigation levels (B) and interaction effect (C) in maize at 60 DAS (pooled data of 2015 and 2016). Means followed by the same letter (s) are not significantly differed by DMRT ( $p=0.05)$. Soil initial N content was $320.3 \mathrm{~kg} \mathrm{ha}^{-1}$ and additionally $150 \mathrm{~kg} \mathrm{~N} \mathrm{ha}^{-1}$ was supplied.

Table 6. Soil moisture content, weeds dry weight and pod borer incidence in response to sowing methods and deficit irrigation in cowpea (pooled data of 2015 and 2016).

\begin{tabular}{|c|c|c|c|c|}
\hline \multicolumn{2}{|c|}{ Treatments } & Soil Moisture Content at 55 DAS (\%) & Weeds DW at 55 DAS $\left(\mathrm{g} \mathrm{m}^{-2}\right)$ & \multirow[t]{2}{*}{ Pod Borer Incidence (\%) } \\
\hline \multicolumn{4}{|c|}{ Sowing methods (L) } & \\
\hline & & $29.27^{\mathrm{a}}$ & $2.81^{\mathrm{a}, *}(7.49)$ & $32.08^{a}$ \\
\hline & & $26.31^{c}$ & $2.41^{\mathrm{c}}(5.45)$ & $25.63^{c}$ \\
\hline & & $27.20^{\mathrm{b}}$ & $2.57^{\mathrm{b}}(6.23)$ & $28.83^{\mathrm{b}}$ \\
\hline & & 0.18 & 0.03 & 0.63 \\
\hline \multicolumn{5}{|c|}{ Irrigation levels (I) } \\
\hline & & $27.67^{\mathrm{a}}$ & $2.58^{\mathrm{a}}(6.28)$ & $28.17^{\mathrm{a}}$ \\
\hline & & $27.51^{\mathrm{a}}$ & $2.60^{\mathrm{a}}(6.40)$ & $28.89^{a}$ \\
\hline & & $27.63^{a}$ & $2.60^{\mathrm{a}}(6.40)$ & $28.89^{a}$ \\
\hline & & $27.56^{\mathrm{a}}$ & $2.61^{\mathrm{a}}(6.47)$ & $29.44^{\mathrm{a}}$ \\
\hline & & 0.16 & 0.02 & 1.20 \\
\hline \multicolumn{5}{|c|}{ Interaction $(\mathrm{I} \times \mathrm{L})$} \\
\hline \multirow{7}{*}{ CF } & $\mathrm{I}_{10 \mathrm{D}}$ & $29.43^{a}$ & $2.79^{\mathrm{a}}(7.38)$ & $30.83^{a-c}$ \\
\hline & $\mathrm{I}_{40}$ & $29.19^{a}$ & $2.80^{\mathrm{a}}(7.45)$ & $33.33^{\mathrm{a}}$ \\
\hline & $\mathrm{I}_{50}$ & $29.17^{\mathrm{a}}$ & $2.82^{\mathrm{a}}(7.57)$ & $31.67^{\mathrm{a}-\mathrm{c}}$ \\
\hline & $\mathrm{I}_{60}$ & $29.30^{a}$ & $2.82^{\mathrm{a}}(7.58)$ & $32.50 \mathrm{ab}$ \\
\hline & $\mathrm{I}_{10 \mathrm{D}}$ & $26.74^{b-d}$ & $2.40^{\mathrm{c}}(5.37)$ & $25.83^{b c}$ \\
\hline & $\mathrm{I}_{40}$ & $26.01^{\mathrm{d}}$ & $2.42^{\mathrm{c}}(5.48)$ & $25.00^{c}$ \\
\hline & $\mathrm{I}_{50}$ & $26.19^{\mathrm{cd}}$ & $2.42^{\mathrm{c}}(5.48)$ & $25.83^{b c}$ \\
\hline
\end{tabular}


Table 6. Cont.

\begin{tabular}{|c|c|c|c|c|}
\hline \multicolumn{2}{|c|}{ Treatments } & Soil Moisture Content at 55 DAS (\%) & Weeds DW at 55 DAS $\left(\mathrm{g} \mathrm{m}^{-2}\right)$ & Pod Borer Incidence (\%) \\
\hline \multirow{5}{*}{ RF } & $\mathrm{I}_{60}$ & $26.29 \mathrm{~cd}$ & $2.42^{\mathrm{c}}(5.48)$ & $25.83 \mathrm{bc}$ \\
\hline & $\mathrm{I}_{10 \mathrm{D}}$ & $26.85^{b-d}$ & $2.55^{\mathrm{b}}(6.11)$ & $27.83^{a-c}$ \\
\hline & $\mathrm{I}_{40}$ & $27.32^{b}$ & $2.58^{b}(6.26)$ & $28.33^{a-c}$ \\
\hline & $\mathrm{I}_{50}$ & $27.52^{b}$ & $2.57^{\mathrm{b}}(6.21)$ & $29.17^{\mathrm{a}-\mathrm{c}}$ \\
\hline & $\mathrm{I}_{60}$ & $27.11^{b c}$ & $2.60^{b}(6.36)$ & $30.00^{a-c}$ \\
\hline \multicolumn{2}{|c|}{ S.Em. \pm} & 0.28 & 0.03 & 2.08 \\
\hline
\end{tabular}

* Data is transformed by using square root transformation $(\sqrt{ } x+0.5)$ and figures in parenthesis indicate original value, Means followed by the same letter (s) within a column are not significantly differed by DMRT ( $p=0.05)$, BBF; broad bed and furrow, CF; corrugated furrow (shallow), RF; ridges and furrow, $\mathrm{I}_{10 \mathrm{D}}$; irrigation once in 10 days, $\mathrm{I}_{40}$; irrigation at $40 \%$ depletion, $\mathrm{I}_{50}$; irrigation at $50 \%$ depletion and $\mathrm{I}_{60}$; irrigation at $60 \%$ depletion.

\subsection{Maize Equivalent Yield of Cowpea (MEY) and System Water-Use Efficiency (WUE)}

The two-year study found that sowing methods were significantly different with respect to MEY of cowpea (Table 7$)$. The RF (9600 kg ha ${ }^{-1}$ ) and CF (9390 kg ha-1) methods recorded higher MEY than the BBF method $\left(8960 \mathrm{~kg} \mathrm{ha}^{-1}\right)$. Of the irrigation levels, irrigation with a higher and moderate depletion $\left(\mathrm{I}_{40}\right.$ and $\left.\mathrm{I}_{50}\right)$ produced a higher MEY (9590 kg ha $\left.{ }^{-1}\right)$ than the other levels. However, irrigation at higher depletion $\left(\mathrm{I}_{60}\right)$ significantly reduced the MEY $\left(8930 \mathrm{~kg} \mathrm{ha}^{-1}\right)$. With respect to the interaction effect of sowing methods and irrigation levels, $\mathrm{CF}+\mathrm{I}_{50}$ treatment produced a much higher MEY (10000 kg ha ${ }^{-1}$ ) than other treatment combinations (Table 7). This treatment has remained at the same level as RF $+\mathrm{I}_{40}\left(9810 \mathrm{~kg} \mathrm{ha}{ }^{-1}\right)$, and $\mathrm{RF}+\mathrm{I}_{50}\left(9720 \mathrm{~kg} \mathrm{ha}{ }^{-1}\right)$. The lowest MEY $\left(8480 \mathrm{~kg} \mathrm{ha}^{-1}\right)$ was recorded in the BBF method $+\mathrm{I}_{60}$. The increase in MEY using the RF $(7.10 \%)$ and CF (4.80\%) methods is mainly due to the increase in grain yield, maize and cowpea yield attributes. Similar results were reported by [44], where the maximum yield in chickpea equivalents was recorded by the RF seeding method in comparison with other methods. The increase in maize grain yield with $\mathrm{CF}+\mathrm{I}_{50}$ was due to better root morphology and yield attributes, as noted by [19]. However, the decrease in MEY with BBF method might be due to the lower maize grain yield and growth parameters. Similarly, increase in MEY under $\mathrm{I}_{40}$ and $\mathrm{I}_{50}$ may be associated with higher maize grain yield and yield attributes [45].

The WUE of maize-cowpea system was influenced $(p<0.05)$ by the sowing methods and irrigation levels (Figure 2). Interestingly, BBF method resulted in higher WUE (14.60 kg ha mm $\mathrm{mm}^{-1}$ ) followed by CF (13.50 kg ha mm$\left.{ }^{-1}\right)$ and RF $\left(11.91 \mathrm{~kg} \mathrm{ha} \mathrm{mm}^{-1}\right)$. Likewise, irrigation at moderate $\left(\mathrm{I}_{50}\right)$ and higher depletion $\left(\mathrm{I}_{60}\right)$ yielded higher WUE (13.53-13.74 kg ha $\mathrm{mm}^{-1}$ ) compared to the lower depletion method $\left(\mathrm{I}_{40}\right)$. Concerning the interaction effect, regardless of irrigation levels the BBF method resulted in higher WUE (14.41-14.93 kg ha $\mathrm{mm}^{-1}$ ) followed by the CF (12.92-13.83 kg ha-mm ${ }^{-1}$ ) and RF (11.24-12.80 kg ha $\mathrm{mm}^{-1}$ ) methods. The higher WUE under BBF method may be due to considerable reduction in the water usage (23.60-33.38\%) across the irrigation levels (Table 7). It may be also due to higher grain yield of cowpea under BBF method due to conserved rain water and improved yield parameters as already reported by [7]. However, $\mathrm{CF}+\mathrm{I}_{50}$ also maintained the higher MEY with $19.33 \%$ reduced water usage compared to $\mathrm{RF}+\mathrm{I}_{40}$. The higher weed growth (density and biomass) under $\mathrm{RF}+\mathrm{I}_{40}$ treatment might have lost considerable soil water through higher transpiration (Table 5), as a result the poor WUE was reported $[14,26]$. Therefore, it is proved from the investigation that CF method of sowing with moderate irrigation $\left(\mathrm{I}_{50}\right)$ could increase the competitive ability of maize against weeds thus, higher yield and WUE of maize-cowpea system was witnessed. 
Table 7. Maize equivalent yield of cowpea (MEY) and total water usage of maize-cowpea system under different sowing methods and irrigation levels (pooled data of 2015 and 2016).

\begin{tabular}{|c|c|c|c|}
\hline \multicolumn{2}{|c|}{ Treatments } & $\operatorname{MEY}\left(\mathrm{kg} \mathrm{ha}^{-1}\right)$ & Total Water Usage (mm) \\
\hline \multicolumn{4}{|c|}{ Sowing methods (L) } \\
\hline \multicolumn{2}{|c|}{ BBF } & $8960^{b}$ & 636.0 \\
\hline \multicolumn{2}{|c|}{ CF } & $9390^{a}$ & 717.6 \\
\hline \multicolumn{2}{|c|}{ RF } & $9600^{a}$ & 816.4 \\
\hline \multirow{2}{*}{\multicolumn{2}{|c|}{ S.Em. \pm}} & 161 & - \\
\hline & & Irrigation levels (I) & \\
\hline \multicolumn{2}{|c|}{$I_{10 D}$} & $9140^{\mathrm{b}}$ & 723.4 \\
\hline \multicolumn{2}{|c|}{$\mathbf{I}_{40}$} & $9590^{a}$ & 781.2 \\
\hline \multicolumn{2}{|c|}{$\mathbf{I}_{50}$} & $9590^{\mathrm{a}}$ & 723.38 \\
\hline \multicolumn{2}{|c|}{$I_{60}$} & $8930^{b}$ & 665.4 \\
\hline \multirow{2}{*}{\multicolumn{2}{|c|}{ S.Em. \pm}} & 144 & - \\
\hline & & Interaction $(\mathrm{I} \times \mathrm{L})$ & \\
\hline \multirow[t]{4}{*}{ BBF } & $\mathrm{I}_{10 \mathrm{D}}$ & $8910^{\mathrm{cd}}$ & 636.0 \\
\hline & $\mathrm{I}_{40}$ & $9390^{a-c}$ & 679.6 \\
\hline & $\mathrm{I}_{50}$ & $9050^{b-d}$ & 636.0 \\
\hline & $\mathrm{I}_{60}$ & $8480^{\mathrm{d}}$ & 592.6 \\
\hline \multirow[t]{4}{*}{ CF } & $\mathrm{I}_{10 \mathrm{D}}$ & $9090^{b-d}$ & 717.6 \\
\hline & $\mathrm{I}_{40}$ & $9560^{a-c}$ & 774.6 \\
\hline & $\begin{array}{l}\mathrm{I}_{50} \\
\mathrm{I}_{50}\end{array}$ & $10000^{a}$ & 717.6 \\
\hline & $\mathrm{I}_{60}$ & $8900 \mathrm{~cd}$ & 660.6 \\
\hline \multirow[t]{5}{*}{$\mathbf{R F}$} & $\mathrm{I}_{10 \mathrm{D}}$ & $9430^{a-c}$ & 816.6 \\
\hline & $\mathrm{I}_{40}$ & $9810^{a b}$ & 889.6 \\
\hline & $\mathrm{I}_{50}$ & $9720^{a-c}$ & 816.6 \\
\hline & $\mathrm{I}_{60}$ & $9410^{a-c}$ & 743.0 \\
\hline & & 249 & - \\
\hline \multicolumn{4}{|c|}{$\begin{array}{l}\text { Means followed by the same letter (s) within a column are not significantly differed by DMRT }(p=0.05) \text {, BB] } \\
\text { broad bed and furrow, CF; corrugated furrow (shallow), RF; ridges and furrow, } \mathrm{I}_{1 \mathrm{OD}} \text {; irrigation once in } 10 \text { day } \\
\mathrm{I}_{40} \text {; irrigation at } 40 \% \text { depletion, } \mathrm{I}_{50} \text {; irrigation at } 50 \% \text { depletion and } \mathrm{I}_{60} \text {; irrigation at } 60 \% \text { depletion. The price } \\
\text { in INR; Indian Rupee ( } \$ 1 \mathrm{USD}=66.7 \mathrm{INR} \text { ) for maize grain }\left(14,000 \mathrm{t}^{-1}\right) \text {, maize stover }\left(600 \mathrm{t}^{-1}\right) \text {, cowpea grai } \\
\text { was }\left(30,000 \mathrm{t}^{-1} \text { ) and cowpea haulm was }\left(1000 \mathrm{t}^{-1}\right) \text {. The effective rainfall (151 and } 74 \mathrm{~mm} \text { during } 2015 \text { and } 201\right. \\
\text { respectively, ) also accounted for total water usage. }\end{array}$} \\
\hline
\end{tabular}
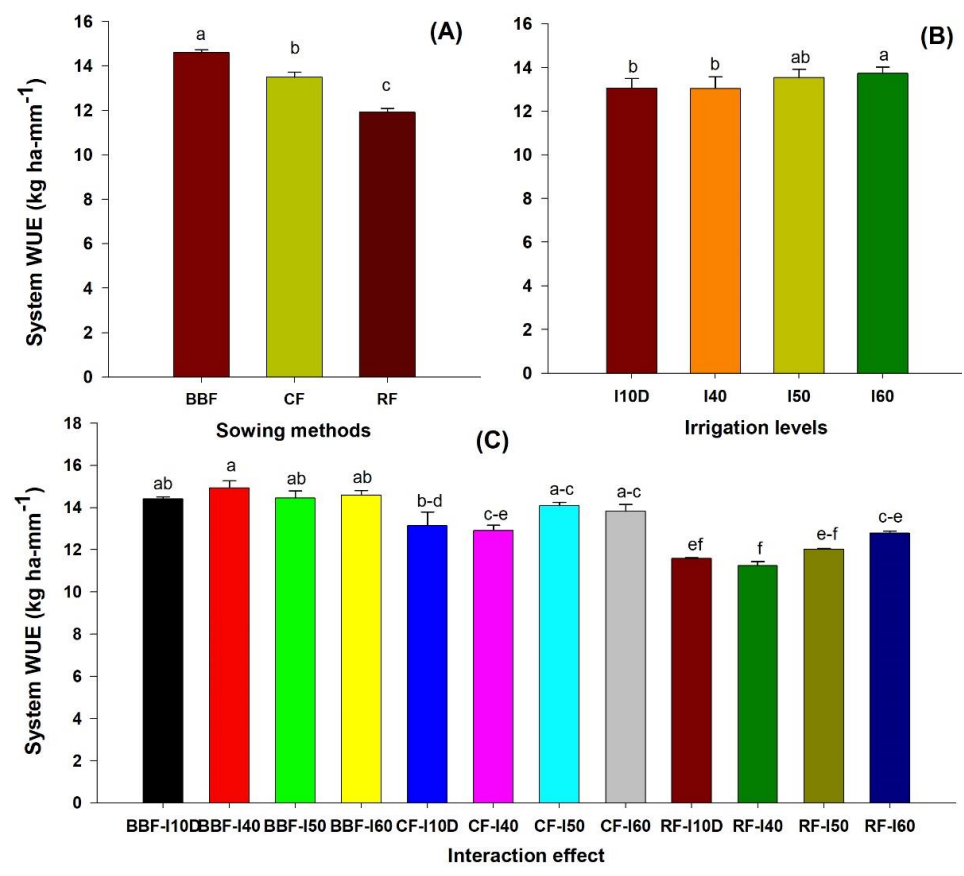

Figure 2. Water-use efficiency (WUE) of maize-cowpea system in response to sowing methods (A), irrigation levels (B) and interaction effect (C). BBF, Broad bed and furrow; CF, Corrugated furrow (shallow); RF, Ridges and furrow; $\mathrm{I}_{10 \mathrm{D}}$, Irrigation once in 10 days; $\mathrm{I}_{40}$, Irrigation at $40 \%$ depletion; $\mathrm{I}_{50}$, Irrigation at $50 \%$ depletion; and $\mathrm{I}_{60}$, Irrigation at $60 \%$ depletion. Means followed by the same letter (s) are not significantly differed by DMRT $(p=0.05)$. 


\section{Conclusions}

In conclusion, weeds are inevitable biological entities in both irrigated and rain-fed crop production. However, changing sowing methods and irrigation levels may influence the weed growth by altering the competitive efficiency of crops. Sowing methods and irrigation levels influenced the monocot, dicot and sedges weeds density and biomass, moisture content and nutrient uptake. The increased water use $(19.33 \%)$ under the RF sowing method with irrigation at $\mathrm{I}_{40}$ and $\mathrm{I}_{50}$ increased weed density and biomass. The occurrence and distribution of weed species were also influenced by the sowing methods and deficit irrigation. The N, P and K uptake of crop and weeds was enhanced as a result of improved soil moisture content and aeration under the RF method with $\mathrm{I}_{40}$ and $\mathrm{I}_{50}$. However, CF method with the moderately irrigation $\left(\mathrm{I}_{50}\right)$ had a higher MEY by improving the WUE of the system (20.22\%). Irrigation management is essential for the development of a holistic weed management system because water resources become costlier. Therefore, planning irrigation with little stress should be promoted for better crop yield and lesser growth of weeds. Therefore, the practice of $\mathrm{CF}$ and $\mathrm{RF}$ and $\mathrm{I}_{50}$ could be a viable agronomic strategy to enhance the competitiveness of maize, yield and WUE of the maize-cowpea crop sequence in semi-arid region.

Author Contributions: H.M.H. and S.A. conceived, designed and performed the field experiments, and manuscript writing; P.G., R.M., M.S.S., A.M.E.-S., A.A., A.Z.D. and H.O.E., statistical analysis of the experimental data, manuscript writing, reviewing and editing and preparing graphs. All authors have read and agreed to the published version of the manuscript.

Funding: This publication was financially supported by the Vice Deanship of Research Chairs at King Saud University. Authors would like to acknowledge University of Agriculture Sciences, Dharwad for facilitating needful requirements for field experimentation and samples analysis.

Institutional Review Board Statement: Not applicable.

Informed Consent Statement: Not applicable.

Data Availability Statement: All data are provided within this paper.

Acknowledgments: The authors extend their appreciation to the financial support by the Vice Deanship of Research Chairs at King Saud University. Authors would like to acknowledge University of Agriculture Sciences, Dharwad for facilitating needful requirements for field experimentation and samples analysis.

Conflicts of Interest: There is no conflict of interest.

\section{References}

1. Census of India. Provisonal Population Totals, Paper 1 of 2011; India Series 1; Office of the Registrar General \& Census Commissioner: New Delhi, India, 2011.

2. Barik, B.; Ghosh, S.; Sahana, A.S.; Pathak, A.; Sekhar, M. Water-food-energy nexus with changing agricultural scenarios in India during recent decades. Hydrol. Earth Syst. Sci. 2017, 21, 3041-3060. [CrossRef]

3. FAO. AQUASTAT Website. Food and Agriculture Organization of the United Nations (FAO) [WWW Document]. 2016. Available online: http:/ / www.fao.org/nr/water/aquastat/countries_regions/IND/ (accessed on 21 January 2018).

4. Dalin, C.; Wada, Y.; Kastner, T.; Puma, M.J. Groundwater depletion embedded in international food trade. Nature 2017, 543, 700-704. [CrossRef]

5. Harris, F.; Green, R.F.; Joy, E.J.M.; Kayatz, B.; Haines, A.; Dangour, A.D. The water use of Indian diets and socio-demographic factors related to dietary blue water footprint. Sci. Total Environ. 2017, 587-588. [CrossRef] [PubMed]

6. FAO. Food and Agriculture Organisation of the United Nations. Crop Prospects and Food Situation. 2018. Available online: http:/ / www.fao.org/3/I9666EN/i9666en.pdf (accessed on 20 August 2020).

7. Halli, H.M.; Angadi, S.S. Influence of land configuration on rain water use efficiency, yield and economics of cowpea (Vigna unguiculata L.) in maize-cowpea sequence cropping under rainfed condition of Northern Transitional Zone. Legume Res. 2019, 42, 211-215. [CrossRef]

8. Sah, R.P.; Chakraborty, M.; Prasad, K.; Pandit, M.; Tudu, V.K.; Chakravarty, M.K.; Narayan, S.C.; Rana, M.; Moharana, D. Impact of water deficit stress in maize: Phenology and yield components. Sci. Rep. 2020, 10, 2944. [CrossRef]

9. Mbava, N.; Mutema, M.; Zengeni, R.; Shimelis, H.; Chaplot, V. Factors affecting crop water use efficiency: A worldwide meta-analysis. Agric. Water Manag. 2020, 228, 105878. [CrossRef] 
10. Gharde, Y.; Singh, P.K.; Dubey, R.P.; Gupta, P.K. Assessment of yield and economic losses in agriculture due to weeds in India. Crop Prot. 2018, 107, 12-18. [CrossRef]

11. Milberg, P.; Hallgren, E. Yield loss due to weeds in cereals and its large-scale variability in Sweden. Field Crop. Res. 2004, 86, 199-209. [CrossRef]

12. Gupta, K.C.; Gupta, A.K.; Rani, S. Weed management in cowpea [Vigna unguiculata (L.) Wasp.] under rainfed conditions. Int. J. Agric. Sci. 2016, 12, 238-240. [CrossRef]

13. Zimdahl, R.L. Fundamentals of Weed Science, 4th ed.; Academic Press: Cambridge, MA, USA, 2013.

14. Norris, R.F. Water use efficiency as a method for predicting water use by weeds. Weed Technol. 1996, 10, 153-155. [CrossRef]

15. Bastiaans, L.; Paolini, R.; Baumann, D. Focus on ecological weed management: What is hindering adoption? Weed Res. 2008, 48, 481-491. [CrossRef]

16. Chauhan, B.S. Grand challenges in weed management. Front. Agron. 2020, 1, 3. [CrossRef]

17. Fereres, E.; Soriano, A. Deficit irrigation for reducing agricultural water use. J. Exp. Bot. 2007, 58, 147-159. [CrossRef]

18. Zhang, S.; Oweis, M. Effect of irrigation amounts applied with subsurface drip irrigation on corn evapotranspiration, yield, water use efficiency, and dry matter production in a semi-arid climate. Agric. Water Manag. 2008, 95, 895-908.

19. Halli, H.M.; Angadi, S.; Kumar, A.; Govindasamy, P.; Madar, R.; El-Ansary, D.O.; Rashwan, M.A.; Abdelmohsen, S.A.M.; Abdelbacki, A.M.M.; Mahmoud, E.A.; et al. Influence of Planting and Irrigation Levels as Physical Methods on Maize Root Morphological Traits, Grain Yield and Water Productivity in Semi-Arid Region. Agronomy 2021, 11, 294. [CrossRef]

20. Halli, H.M.; Angadi, S.S. Influence of land configuration and deficit irrigation on nutrient uptake and grain yield of maize (Zea mays L.). J. Farm. Sci. 2019, 32, 397-402.

21. Pereira, L.S.; Owas, T.; Aziz, A. Irrigation management under water scarcity. Agric. Water Manag. 2008, 57, 175-206. [CrossRef]

22. Halli, H.M.; Angadi, S.S. Response of land configuration and deficit irrigation on growth and yield attributes of maize (Zea mays L.). Int. J. Curr. Microbiol. App. Sci. 2017, 6, 52-60. [CrossRef]

23. Choudhary, V.K. Response of land configuration and mulches on maize-frenchbean-toria cropping system. Agron. J. 2016, 108, 2147-2157. [CrossRef]

24. Choudhary, V.K.; Bhagawati, R. Planting method, row arrangement and crop residue mulch influence on weed dynamics and productivity of toria mustard. Indian J. Weed Sci. 2019, 51, 298-301. [CrossRef]

25. El-Metwally, I.M.; Abido, W.A.E.; Saadoon, S.M.; Gad, S.B. The integrated effect of deficit irrigation and weed control treatments on peanut productivity under sandy soil conditions with reference to nematode infection. Plant Arch. 2020, 20, 2581-2593.

26. Coolong, C. Using Irrigation to Manage Weeds-A Focus on Drip Irrigation; IBM Publishers: New York, NY, USA, 2013; pp. 1-20. [CrossRef]

27. Grattan, S.R.; Schwankl, L.J.; Lanini, W.T. Weed control by subsurface drip irrigation. Calif. Agric. 1988, $42,22-24$.

28. Piper, C.S. Soil and Plant Analysis; University of Adelaide, Australia Academic Press: New York, NY, USA, 1966 ; pp. 14-32.

29. Black, C.A. Methods of Soil Analysis, Part II Agronomy Monograph No. 9; American Society of Agronomy: Madison, WI, USA, 1967; p. 148.

30. Veihmeyer, F.J.; Hendrickson, A.H. Methods of measuring field capacity and wilting percentage of soils. Soil Sci. 1949, 68, 75-94. [CrossRef]

31. Jackson, M.L. Soil Chemical Analysis; Prentice Hall India PVT. Ltd.: New Delhi, India, 1973; p. 498.

32. Subbiah, B.V.; Asija, G.L. A rapid procedure for the estimation of available nitrogen in soils. Curr. Sci. 1956, 25, 259-260.

33. Li, J.; Ji, H.; Li, B.; Liu, Y. Wetting patterns and nitrate distributions in layered-textural soils under drip irrigation. J. Agric. Sci. China 2007, 6, 970-980. [CrossRef]

34. Francis, C.A. (Ed.) Distribution and importance of multiple cropping. In Multiple Cropping Systems; MacMillan Publishing Company: New York, NY, USA, 1986.

35. Gomez, K.A.; Gomez, A.A. Statistical Procedure for Agriculture Research, 2nd ed.; John Willey and Sons: New York, NY, USA, 1984; p. 680 .

36. Bartlett, M.S. The use of transformation. Biom. Bull. 1947, 3, 39-52. [CrossRef]

37. Pal, D.; Dwivedi, A.; Singh, R.; Kumar, K.; Singh, A.; Tomar, S.S. Integrated effect of land configurations and weed management regimes on weed dynamics and performance of urdbean (Vigna mungo L. Hepper) in an alluvial soil. Indian J. Sci. Technol. 2015, 8 , 1-6. [CrossRef]

38. Hussein, F.A.; El-Saeid, H.M.; El-Said-Amin, A.B.A. Water loss by weeds: A review. Int. J. ChemTech Res. 2015, 7, 323-336.

39. Saini, M.; Walia, U.S. Effect of land configuration and weed management in onion (Allium cepa). Indian J. Agron. 2012, 57, 275-278.

40. Subbarao, G.; Patil, R.G. Nutrient content, uptake and yield of rainfed groundnut as influenced by moisture conservation practices and nutrient management. J. Indian Soc. Coast. Agric. Res. 2005, 23, 34-38.

41. Fusheng, L.; Jihua, L.; Shaozhong, K.; Jianhua, Z. Benefits of alternate partial root-zone irrigation on growth, water and nitrogen use efficiencies modified by fertilization and soil water status in maize. Plant Soil. 2007, 295, 279-291.

42. Hossain, M.A.; Haque, M.A.; Azizul, M.; Prodhan, M.Z.H. Incidence and Damage Severity of Pod Borer, Helicoverpa Armigera (Hubner) in Chickpea (Cicer Arietinum L.). Bangladesh J. Sci. Ind. Res. 2008, 44, 221-224. [CrossRef]

43. Selvaraju, R.; Subbian, P.; Balasubramanian, P.; Lal, R. Land configuration and soil nutrient management options for sustainable crop production on Alfisols and Vertisols of southern peninsular India. Soil Tillage Res. 1999, 52, 203-216. [CrossRef] 
44. Tumbare, A.D.; Bhoite, S.U. Effect of moisture conservation techniques on growth and yield of pearl millet-gram sequence in watershed. Indian J. Dryland. Agric. Res. Dev. 2000, 15, 94-95.

45. Mandal, K.G.; Hati, K.M.; Misra, A.K.; Bandyopadhyay, K.K.; Tripathi, A.K. Land surface modification and crop diversification for enhancing productivity of a Vertisols. Int. J. Plant Prod. 2013, 7, 6814-6818. 